\title{
Sistem Inferensi Fuzzy Untuk Membantu Diagnosis Penyakit Pneumonia Anak
}

\author{
Nu'man ${ }^{1}$, Sri Kusumadewi ${ }^{2}$, Nurlaili Muzayyanah ${ }^{3}$ \\ Jurusan Teknik Informatika, Fakultas Teknologi Industri , Universitas Islam Indonesia ${ }^{1}$ \\ Fakultas Teknologi Industri, Universitas Islam Indonesia ${ }^{2}$ \\ Fakultas Kedokteran, Universitas Islam Indonesia ${ }^{3}$ \\ 16917217@students.uii.ac.id ${ }^{1}$, sri.kusumadewi@uii.ac.id², nurlailimuzayyanah@yahoo.com³
}

\begin{tabular}{l}
\hline \hline Article Info \\
\hline History : \\
Dikirim 26 Mei 2020 \\
Direvisi 18 Juni 2020 \\
Diterima 14 Juli 2020
\end{tabular}

Kata Kunci :

Diagnosis

Fuzzy Tsukamoto

Pneumonia

\begin{abstract}
Abstrak
Pneumonia merupakan penyakit yang dapat menyerang semua kalangan umur, mulai dari balita sampai dengan dewasa. Dokter sering menemukan pasien yang datang ke rumah sakit sudah mengalami pneumonia berat. Pneumonia memiliki beberapa tingkatan klasifikasi, ada pneumonia ringan dan pneumonia berat. Karena pneumonia memiliki beberapa tingkatan klasifikasi sehingga memungkinkan gejala yang dialami juga berbeda. Ketepatan dalam penegakan diagnosis sangat penting, karena kesalahan diagnosis dapat berakibat fatal pada kesehatan anak. Penelitian ini menggunakan fuzzy tsukamoto untuk membantu diagnosis pnuemonia anak. Input sistem diperoleh dari gejala klinis yang diderita anak, seperti batuk, sesak napas, napas cepat, retraksi dan lainya. Basis pengetahuan diperoleh dari pakar dan dibangun dengan kaidah (IF-THEN). Selanjutnya fire strength yang diperoleh pada setiap aturan fuzzy dikomposisikan menggunakan rata-rata terbobot. Hasil rata-rata terbobot ini merupakan output diagnosis penyakit. Berdasarkan hasil uji coba dengan 10 data uji, fuzzy tsukamoto berhasil memberikan rekomendasi diagnosis 8 dari 10 data yang sesuai dengan hasil rekam medis. Fuzzy tsukamoto memberikan akurasi sebesar $80 \%$, sensitifitas sebesar $75 \%$ dan spesitifitas sebesar $83 \%$.
\end{abstract}

(C) This work is licensed under a Creative Commons Attribution-ShareAlike 4.0 International License.

\footnotetext{
Koresponden:

Nu'man

Program Magister Teknik Informatika, Fakultas Teknologi Industri

Universitas Islam Indonesia

Jl. Kaliurang KM 14.5, Sleman, Yogyakarta, 55584

Email : 16917217@students.uii.ac.id
}

\section{PENDAHULUAN}

Pneumonia merupakan salah satu penyakit infeksi saluran pernapasan yang menyebabkan kematian tertinggi pada anak di Indonesia [1]. Pneumonia adalah infeksi akut yang mengenai jaringan paru-paru (alveoli) yang dapat disebabkan oleh berbagai mikroorganisme seperti virus, jamur dan bakteri [2]. Beberapa bakteri yang biasa menyebabkan pneumonia pada anak adalah Streptococcus Pneumoniae, Haemophillus Influenza tipe B, Staphyloccus aureus dan Mycoplasma pneumoniae [3]. Virus lebih sering ditemukan pada anak kurang dari 5 tahun. Respiratory syncytial virus (RSV) merupakan virus penyebab tersering pada anak dibawah 3 tahun [4]. 
Berdasarkan data laporan rutin Subdit ISPA Tahun 2018, didapatkan insiden (per 1000 balita) di Indonesia sebesar 20.06\% hampir sama dengan data tahun sebelumnya $20.56 \%$ [2]. Data dari Riset Kesehatan Dasar (RISKESDAS) menyebutkan period prevalens dan prevalensi dari pneumonia tahun 2013 adalah 1.8\% dan 4.5\% [5]. Angka kematian akibat pneumonia pada balita tahun 2016 sebesar 0,22\%, kemudian pada tahun 2017 mengalami kenaikan menjadi $0,34 \%$. Sedangkan angka kematian akibat Pneumonia pada kelompok anak umur 1 - 4 tahun pada 2017 sebesar $0.23 \%$ [6]. Persentase kejadian pneumonia anak diindonesia terdapat gambar 1.

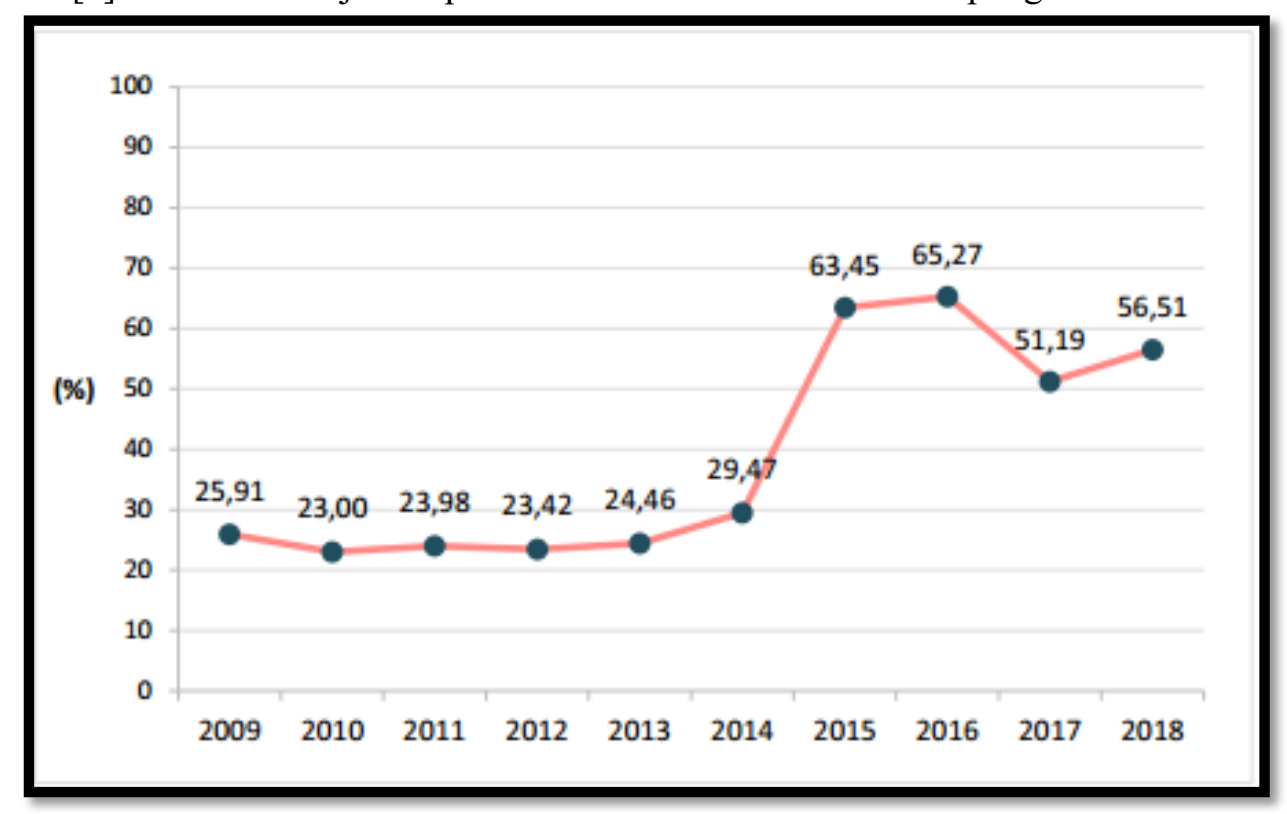

Gambar 1. Ditjen P2P, Kemenkes RI, 2019.

Gejala pneumonia memiliki kemiripan dengan gejala batuk biasa, sehingga masyarakat tidak begitu percaya dan peduli terhadap gejala yang biasanya muncul, hal ini terjadi karena kurangnya pengetahuan masyakarat tentang pneumonia [7]. Umumnya pasien yang datang ke dokter sudah mengalami gejala pneumonia berat, kondisi tersebut dapat membahayakan kesehatan dan keselamatan anak, sehingga perawatan yang diberikan juga tidak maksimal. [8].

Beberapa penelitian terkait sebelumnya, penelitian [9], meneliti tentang pengembangan sistem menggunakan algoritma K-NN untuk mengenali dan melakukan penanganan terhadap penyakit pneumonia pada balita dengan nilai similarity terbesar adalah $81 \%$ dan termasuk pneumonia berat. Yang diperoleh dengan melakukan perhitungan jarak dan nilai similarity antara data testing dan training. Penelitian lainnya [7], melakukan diagnosis pneumonia menggunakan case based reasoning, diagnosis ditegakkan berdasarkan input gejala yang dimasukkan pasien seperti sesak napas, batuk, demam dan lain sebagainya. Hasilnya sistem yang mampu membantu orang tua untuk diagnosis dan mencegah penyakit pneumonia pada anak dengan nilai similirity sebesar $45.5 \%$.

Berdasarkan pemaparan serta fakta-fakta yang ada, untuk mengatasi permasalahan tersebut maka dibutuhkan sebuah sistem yang dapat membantu proses diagnosis pneumonia pada anak berdasarkan gejala, pemeriksaan fisik serta pemeriksaan penunjang. Salah satu metode yang cocok dipakai adalah logika fuzzy. Logika fuzzy mampu memberikan nilai bagi suatu ketidakjelasan dan ketidakpastian dari berbagai variabel diagnosis pneumonia seperti lambat, normal, dan cepat [10][11]. Metode tsukamoto merupakan salah satu bentuk logika fuzzy yang bersifat intuitif yang dapat memberikan tanggapan berdasarkan informasi yang bersifat kualitatif, tidak akurat dan ambigu [10]. Diharapkan dengan model ini dapat membantu dokter mendiagnosis pneumonia, sehingga penanganan yang cepat serta penatalaksanaan yang benar dapat diberikan kepada pasien dengan lebih baik. 


\section{METODE PENELITIAN}

\subsection{Tahapan Penelitian}

Tahapan penelitian dibuat agar dapat mengetahui gambaran yang dibuat secara sistematis dan dijadikan pedoman dalam menyelesaikan permasalahan terdapat gambar 2. Adapun tahapan penelitian pada penelitian ini terdiri dari (i) Analisis Kebutuhan, (ii) Pengumpulan Data, (iii) Perancangan dan Pemodelan, (iv) Pengembangan Sistem, dan (v) Pengujian.

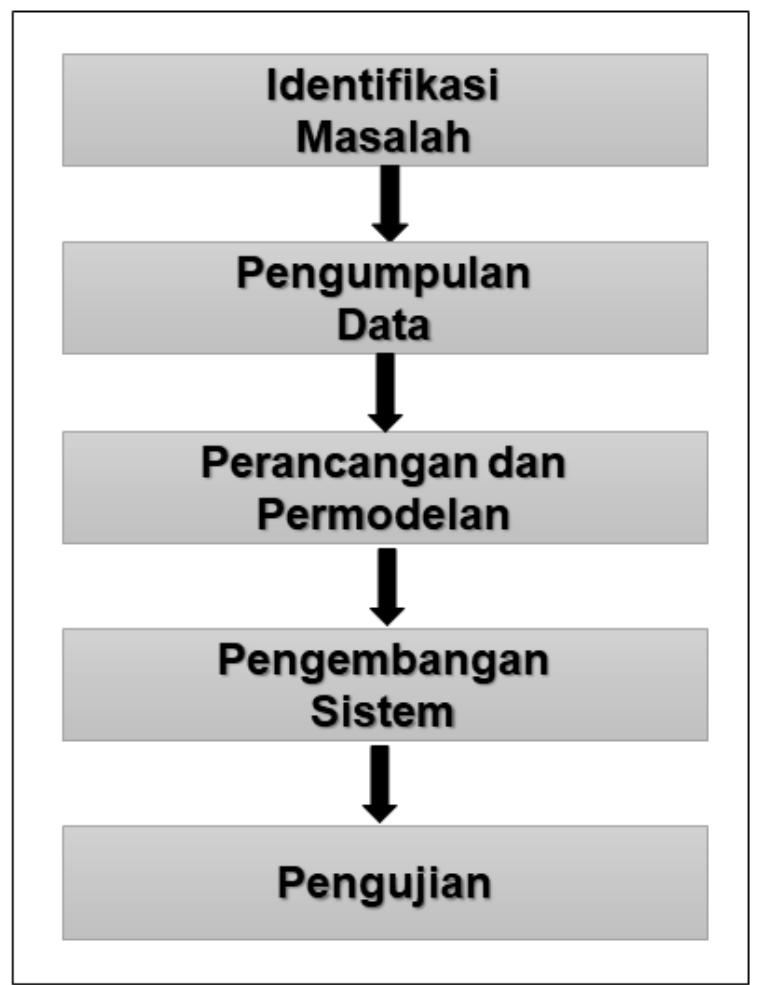

Gambar 2. Tahapan Penelitian.

1. Identifikasi Masalah

Tahap ini melakukan identifikasi untuk memperoleh informasi tentang permasalahan pneumonia anak. Mulai dari permasalahan yang dihadapi dokter dilapangan, tingkat resiko penyakit pneumonia anak dan gejala gejala yang umumnya terjadi pada anak penderita pneumonia.

2. Pengumpulan Data

Pengumpulan data dilakukan dengan melakukan observasi di salah satu rumah sakit di Yogyakarta. Melakukan wawancara kepada pakar (dokter spesialis anak) dan kepala IT dirumah sakit. Kemudian melakukan pengambilan data dengan range anak yang termasuk dalam kategori balita (1-5 Tahun). Data yang digunakan dalam penelitian sebanyak 30 Data.

3. Perancangan dan Pemodelan

Aktifitas pada tahap ini merancang gambaran umum sistem, kemudian melakukan pemodelan untuk penegakan diagnosis dan melakukan pembuatan antarmuka sistem. Gambar 3 meruapakan gambaran umum sistem yang dibuat. 


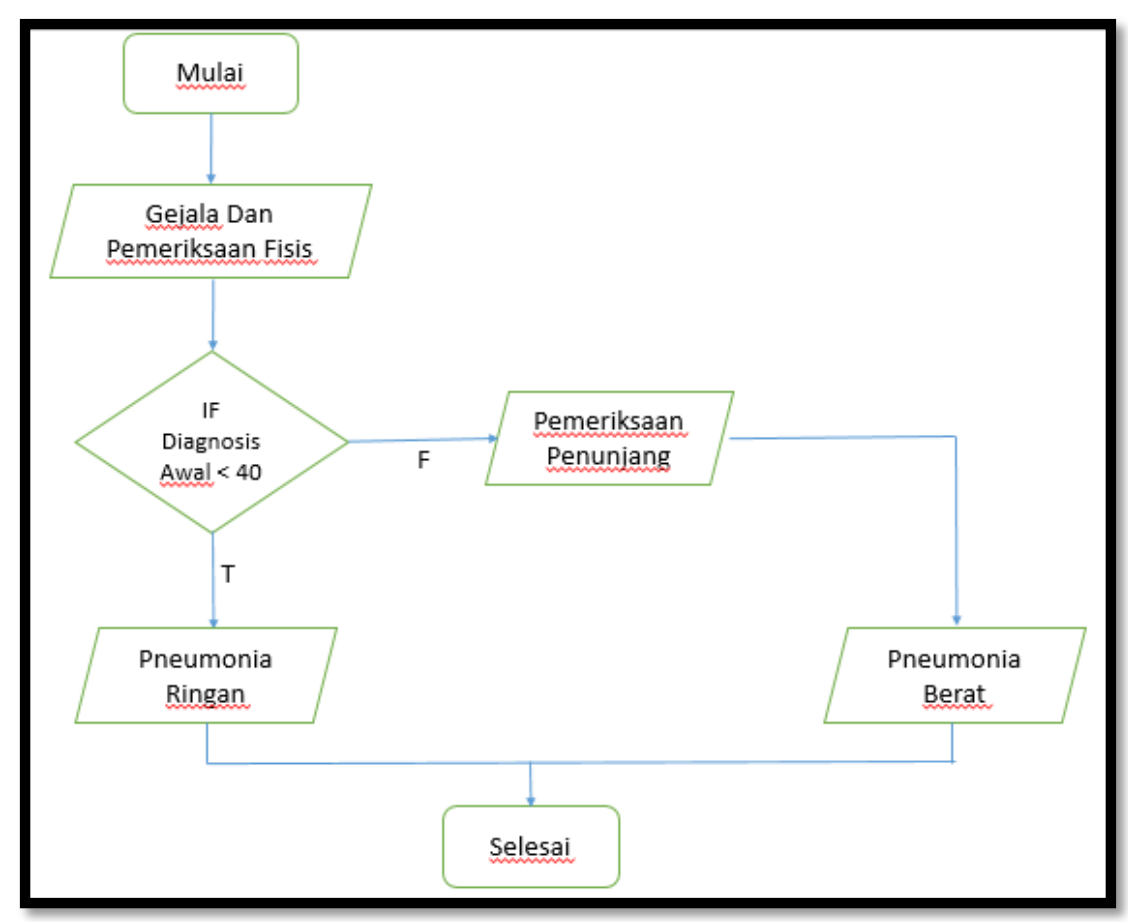

Gambar 3. Gambaran Umum Sistem.

Gambar 3 merupakan gambaran umum sistem, dimulai dengan proses menginputkan gejala yang diderita oleh pasien dan hasil pemeriksaan fisis yang dilakukan oleh dokter, seperti batuk, napas cepat, wheezing dan lain lainnya. Lalu sistem mencari klasifikasi pneumonia berdasarkan input yang dimasukkan. Apabila hasil pencarian sistem tidak ditemukan gejala pneumonia berat sistem akan menyelesaikan pencarian dan mengeluarkan diagnosis pneumonia ringan akan tetapi apabila sistem menemukan adanya indikasi pneumonia berat, makan sistem akan meminta hasil pemeriksaan lain sebagai pendukung hasil diagnosis, seperti leukosit dan lainnya.

4. Pengembangan Sistem

Proses pada tahap ini melakukan penerapan semua hasil rancangan dan pemodelan yang telah dibuat kedalam perangkat lunak. Menjalankan sistem yang dibuat dan memastikan semua fungsi sudah berjalan dengan baik.

5. Pengujian

Tahap pengujian dan validasi untuk mengetahui karakteristik sistem dan mengidentifikasi jika terdapat ketidakkonsistenan dalam sistem. Pengujian dilakukan menggunakan confusion matrix. Terdapat 4 istilah sebagai representasi hasil proses klasifikasi pada confusion matrix. Keempat istilah tersebut adalah True Positive (TP), True Negative (TN), False Positive (FP) dan False Negative (FN).

\subsection{Konsep Teori}

1. Pneumonia

Menurut Pedoman Pelayanan Medis IDAI, Pneumonia adalah infeksi akut parenkim paru yang meliputi alveolus dan jaringan interstitial [4]. Secara klinis pneumonia didefinisikan sebagai suatu peradangan paru yang disebabkan oleh mikroorganisme (bakteri, virus, jamur, parasit) [3]. Ciri khas pneumonia pada anak dipengaruhi oleh usia dari anak tersebut, usia akan membedakan spektrum etiologi, gambaran klinis, serta strategi pengobatannya.

Gambaran klinis pneumonia pada anak umumnya ringan hingga berat. Gejala umum yang biasa dialami seperti demam, gelisah, penurunan napsu makan dan lainnya. Sedangkan gejala gangguan respiratori seperti batuk, sesak napas, takipnea, dan retraksi 
dada [3], [4]. Pneumonia pada balita diklasifikasikan sesuai gejala atau tanda dan akan diberikan tindakan dan pelayanan kesehatan yang sesuai dengan kondisi balita tersebut. Berikut ini adalah klasifikasi pneumonia berdasarkan pedoman respirologi pada anak, antara lain [3], [4], [12]:

a. Pneumonia Berat, Pada saat dilakukan pemeriksaan ditemukan tarikan dinding dada bagian bawah kedalam (TTDK) atau saturasi oksigen $<90$ pada balita. Klasifikasi pneumonia ini harus dirawat dan diberikan antibiotik.

b. Pneumonia Ringan, Pada saat proses pemeriksaan tidak ditemukan tarikan dinding dada bagian bawah kedalam (TTDK), akan tetapi ditemukan napas cepat $50 \mathrm{x} / \mathrm{menit}$ pada anak 2 bulan sampai 12 bulan dan $40 \mathrm{x} /$ menit atau lebih pada anak 12 bulan sampai 59 bulan. Klasifikasi pneumonia ini tidak harus dirawat tetapi diberikan antibiotic oral.

\section{Logika Fuzzy}

Logika Fuzzy pertama kali diperkenalkan oleh Prof. Lotfi A. Zadeh pada tahun 1965. Dasar logika fuzzy adalah teori himpunan fuzzy. Pada teori himpunan fuzzy, peranan derajat keanggotaan sebagai penentu keberadaan elemen dalam suatu himpunan sangatlah penting. Nilai keanggotaan atau derajat keanggotaan atau membership function menjadi ciri utama dari penalaran dengan fuzzy logic tersebut [13]. Logika fuzzy dapat diangggap sebagai kotak hitam yang menghubungkan antara ruang input dengan ruang output. Kotak hitam tersebut berisi cara atau metode yang dapat digunakan untuk mengolah data input menjadi output dalam bentuk informasi yang baik [13].

Fungsi keanggotaan adalah suatu kurva yang menunjukkan pemetaan titik-titik input ke dalam nilai keanggotaan yang memiliki interval 0 sampai 1 . Salah satu cara yang dapat digunakan untuk mendapatkan nilai keanggotaan adalah dengan melalui pendekatan fungsi. Beberapa fungsi keanggotaan fuzzy, yaitu [11]:

a. Representasi Linier

Pada representasi linier, pemetaan input ke derajat keanggotaannya digambarkan sebagai garis lurus. Ada 2 keadaan himpunan fuzzy yang linier. Pertama, Kenaikan himpunan dimulai pada nilai domain yang memiliki derajat keanggotaan nol [0] bergerak ke kanan menuju nilai domain yang memilki derajat keanggotaan lebih tinggi. Kedua, Garis lurus dimulai dari nilai domain dengan derajat keanggotaan tertinggi pada sisi kiri, kemudian bergerak menurun ke nilai domain yang memiliki derajat keanggotaan lebih rendah.

b. Representasi Kurva Segitiga

Kurva segitiga pada dasarnya merupakan gabungan antara 2 garis (linier).

c. Representasi Kurva Trapesium

Kurva trapesium pada dasarnya seperti bentuk segitiga, hanya saja pada rentang tertentu ada beberapa titik yang memiliki nilai keanggotaan 1 [11].

3. Fuzzy Tsukamoto

Metode tsukamoto adalah perluasan dari penalaran monoton. Setiap konsekuen pada aturan berbentuk IF-THEN harus dipresentasikan dengan suatu himpunan fuzzy dengan fungsi keanggotaan yang menoton. Output hasil inferensi dari tiap-tiap aturan diberikan secara tegas (crisp) berdasarkan $\alpha$-predikat (fire strength). Proses agregasi antar aturan dilakukan, dan hasil akhirnya diperoleh dengan menggunakan defuzzy dengan konsep ratarata terbobot [11].

Rata rata terbobot sebagai berikut:

$$
z=\frac{a_{1} z_{1}+a_{2} z_{2}+\cdots+a_{n}}{a_{1}+a_{2}+\cdots a_{n}}
$$




\section{HASIL DAN PEMBAHASAN}

\subsection{Model Fuzzy Tsukamoto}

1. Fuzzyfikasi

Langkah awal dari perancangan mesin inferensi fuzzy adalah menentukan himpunan fuzzy dari tiap-tiap variabel fuzzy. Tabel 1 memaparkan batasan variabel dan himpunan fuzzy sebagai inputan di mesin inferensi fuzzy. Tabel 2 terkait variabel non fuzzy yang memiliki nilai pasti yaitu YA dan TIDAK, dan tabel 3 berisi himpunan fuzzy yang memiliki range yang diperoleh dari pengetahuan pakar.

Tabel 1. Variabel Fuzzy.

\begin{tabular}{lllllr}
\hline No & Fungsi & Kode & $\begin{array}{l}\text { Nama } \\
\text { Variabel }\end{array}$ & $\begin{array}{l}\text { Semesta } \\
\text { Pembicaraan }\end{array}$ & Satuan \\
\hline 1 & Input & GP01 & Detak Jantung & {$[70,110]$} & $\mathrm{x} /$ menit \\
& & GP02 & Pernapasan & {$[20,40]$} & x/menit \\
& & GP03 & Suhu Tubuh & {$[35,38]$} & Celcius \\
& & GP04 & Leukosit & {$[6000,15000]$} & $/ \mathrm{mm}^{3}$ \\
2 & Output & & Pneumonia Ringan & \\
& & & \multicolumn{3}{c}{ Pneumonia Berat } \\
\hline
\end{tabular}

Tabel 2. Variabel Non Fuzzy.

\begin{tabular}{llll}
\hline No & Fungsi & Kode & Nama Variabel \\
\hline 1 & Input & GP05 & Batuk \\
2 & & GP06 & Sesak Napas \\
3 & & GP07 & Pernapasan Cuping Hidung \\
4 & & GP08 & Wheezing \\
5 & & GP09 & Ronchi \\
6 & & GP10 & Retraksi \\
7 & & GP11 & Sianosis \\
8 & & GP12 & Kesulitan Makan Minum \\
9 & GP13 & Letargis \\
10 & & GP14 & Kejang \\
11 & & GP15 & Foto Toraks \\
\hline
\end{tabular}

Tabel 3. Himpunan Fuzzy.

\begin{tabular}{llllr}
\hline No & Kode & Variabel & Himpunan Fuzzy & \multicolumn{1}{c}{ Domain } \\
\hline 1 & GP01 & Detak & Lambat & {$[70-80]$} \\
& & Jantung & Normal & {$[70-110]$} \\
& & $(\mathrm{x} /$ menit $)$ & & \\
& & & Cepat & {$[100-110]$} \\
2 & GP02 & Pernapasan & Lambat & {$[20-25]$} \\
& & $(\mathrm{x} /$ menit $)$ & Normal & {$[20-40]$} \\
& & & Cepat & {$[35-40]$} \\
3 & GP03 & Suhu & Normal & {$[35-40]$} \\
& & (celcius) & Demam & {$[37.5-40]$} \\
4 & GP04 & Leukosit & Rendah & {$[6000-9000]$} \\
& & $(/$ mm) & Normal & {$[6000-15000]$} \\
& & & Tinggi & {$[12000-15000]$} \\
\hline
\end{tabular}

Variabel non fuzzy memiliki nilai keanggotaan 1 dan 0 . Nilai 1 jika variabelnya ADA dan bernilai 0 jika variabelnya TIDAK ADA. 
2. Basis Pengetahuan Fuzzy

Basis pengetahuan dalam perancangan sistem ini sangatlah diperlukan yang berisi aturan-aturan atau rule yang berguna dalam penentuan keputusan sebagai hasil output sistem. Aturan diperoleh dari Pedoman Pelayanan Medis IDAI, serta wawancara dengan dokter spesialis anak. Jumlah aturan atau rule yang digunakan pada sistem sebanyak 30 aturan. Tabel 4 merupakan contoh aturan atau rule yang digunakan sebagai dasar penentuan keputusan sebagai berikut.

Tabel 4. Aturan

\begin{tabular}{lcccc}
\hline Rule & IF & \multicolumn{1}{c}{ Kondisi } & Then & Pneumonia \\
\hline R1 & IF & GP01 Cepat AND GP02 Cepat AND GP03 Panas AND & Then & Pneumonia \\
& & GP04 Tinggi AND GP05 Ya AND GP06 Ya AND GP07 Ya & & Berat \\
& & AND GP08 Ya AND GP09 Ya AND GP10 Ya AND GP11 Ya & & \\
& & AND GP12 Ya AND GP13 Ya AND GP14 Ya AND GP15 Ya & & \\
\hline- & - & - & - & - \\
\hline R30 & IF & GP01 Normal AND GP02 Cepat AND GP03 Normal AND & Then & Pneumonia \\
& & GP04 Tinggi AND GP05 Ya AND GP06 Ya AND GP07 Ya & & Ringan \\
& AND GP08 Ya AND GP09 Ya AND GP10 Tidak AND GP11 & & \\
& Tidak AND GP12 Tidak AND GP13 Tidak AND GP14 Tidak & & \\
& AND GP15 Tidak & & \\
\hline &
\end{tabular}

3. Mesin inferensi

Mesin inferensi merupakan proses mengubah input fuzzy menjadi output fuzzy dengan mengikuti rules yang sudah ada. Dalam proses inferensi metode fuzzy tsukamoto menggunakan fungsi implikasi MIN untuk mendapatkan nilai $\alpha$-predikat tiap-tiap rules $(\alpha 1$, $\alpha 2, \alpha 3 \ldots \alpha$ n). Kemudian masing - masing nilai $\alpha$-predikat ini digunakan untuk menghitung keluaran hasil inferensi secara tegas (crips) masing- masing rules (z1, z2, z3 .... zn) [14].

4. Defuzzyfikasi

Langkah terakhir dari tahapan metode fuzzy tsukamoto adalah melakukan defuzzifikasi atau mengubah nilai himpunan fuzzy menjadi nilai tegas atau crisp. Setelah didapatkan nilai alpha-predikat, selanjutnya adalah proses menghitung nilai setiap konsekuen setiap rules atau nilai z. Defuzzifikasi dilakukan dengan cara membagi nilai sigma alpha-predikat dikali $\mathrm{z}$ dengan sigma alpha-predikat.

\subsection{Implementasi}

Tampilan ini merupakan halaman diagnosis dan hasil pemeriksaan yang dilakukan oleh dokter. Dokter dapat melakukan pemeriksaan terhadap pasien dengan menginputkan gejala yang diderita pasien. Kemudian sistem melakukan proses diagnosis. Gambar 4 merupakan halaman diagnosis, berisi semua data yang diperoleh dari wawancara dan pemeriksaan, dan gambar 5 adalah hasil akhir dari proses diagnosis, yang dijadikan pendukung pakar dalam menegakkan diagnosis akhir. 


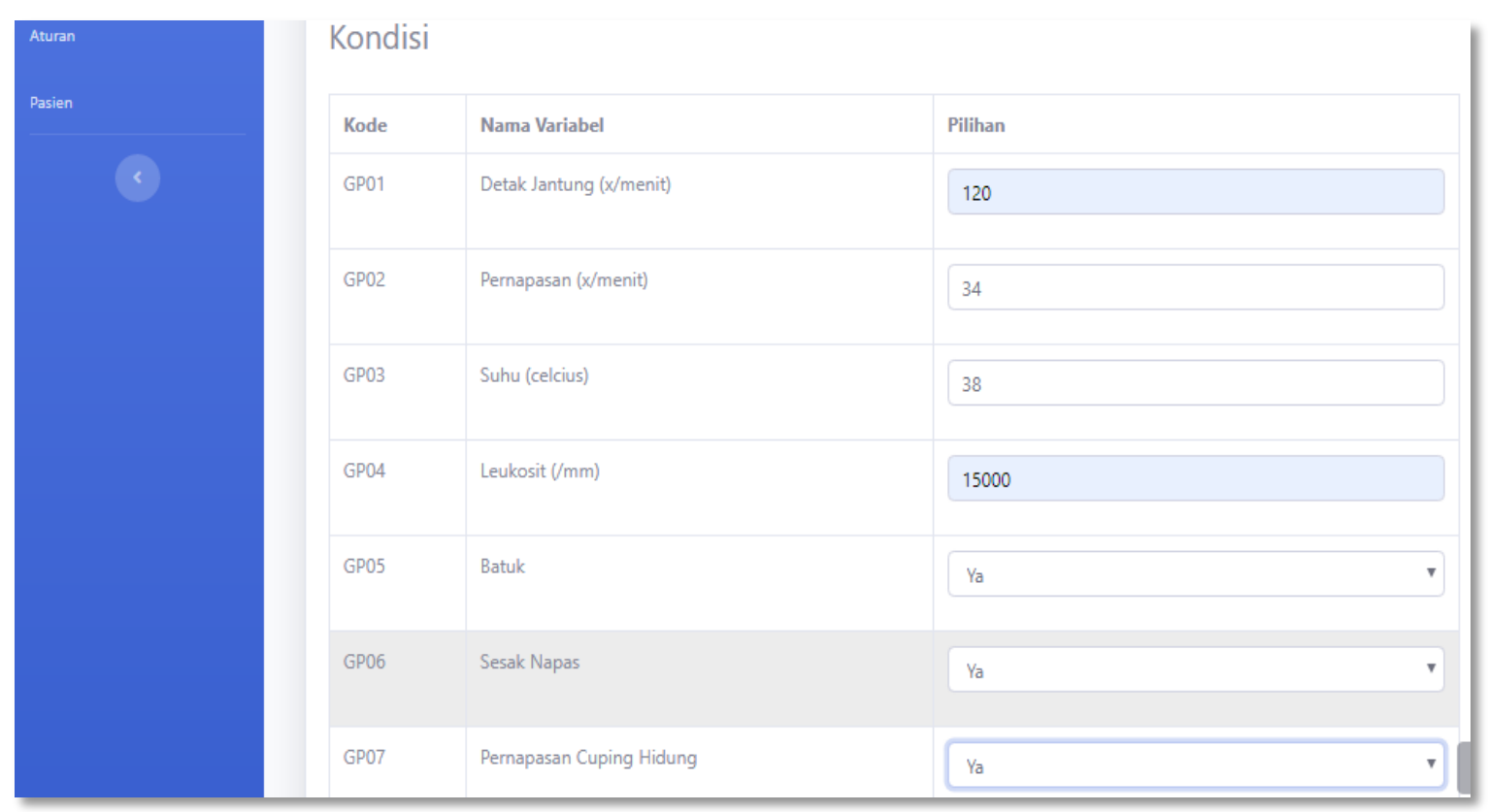

Gambar 4. Halaman Diagnosis.

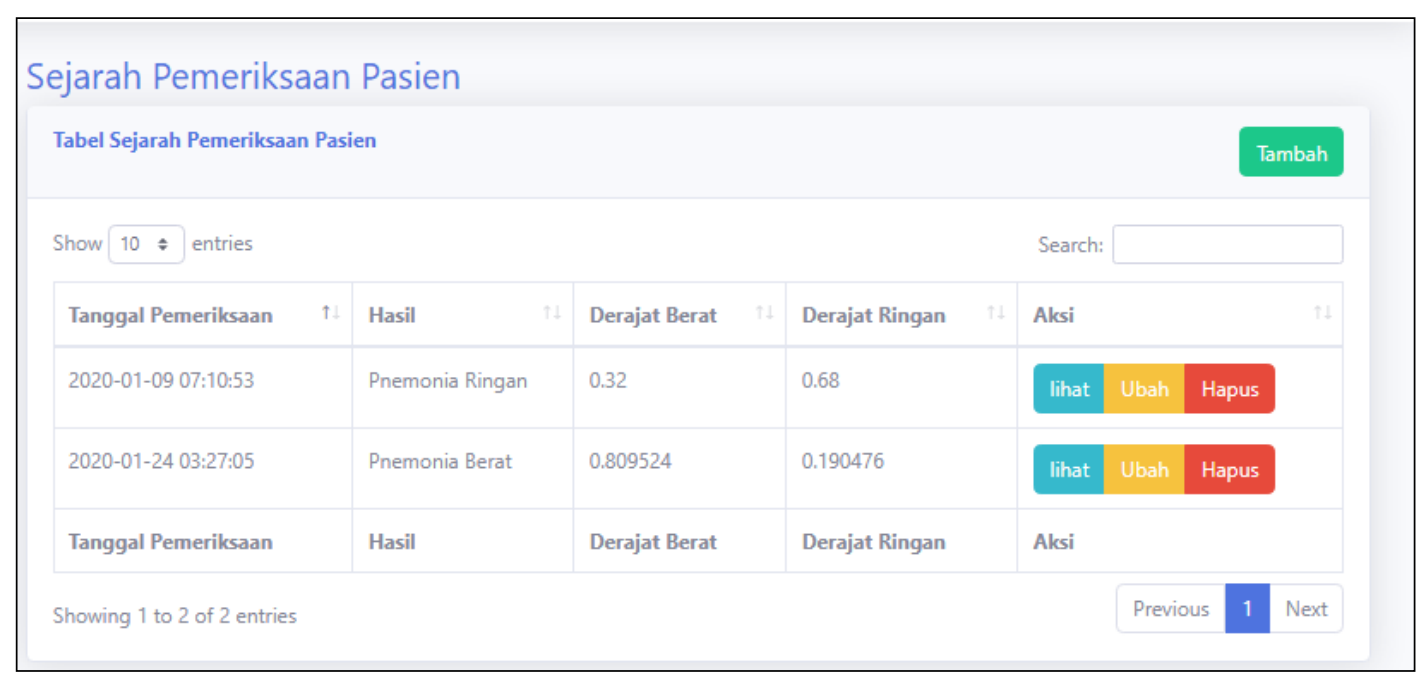

Gambar 5. Halaman Hasil Pemeriksaan.

\subsection{Pengujian}

Hasil pengujian validitas sistem direpresentasikan menggunakan single decision theshold (one feature) antara data rekam medis dengan sistem yang dibuat. Tabel 5 merupakan tabel hasil pengujian dari 10 data uji:

Tabel 5. Hasil Pengujian

\begin{tabular}{lllcl}
\hline Data Ke & Rekam Medis & Sistem & Nilai Persentase & Keterangan \\
\hline $\mathbf{1}$ & Ringan & Ringan & $85 \%$ & SESUAI \\
$\mathbf{2}$ & Ringan & Ringan & $80 \%$ & SESUAI \\
$\mathbf{3}$ & Berat & Berat & $80 \%$ & SESUAI \\
$\mathbf{4}$ & Ringan & Ringan & $70 \%$ & SESUAI \\
$\mathbf{5}$ & Berat & Berat & $89 \%$ & SESUAI \\
$\mathbf{6}$ & Ringan & Berat & $\mathbf{6 3 \%}$ & TIDAK SESUAI \\
\hline
\end{tabular}




\begin{tabular}{lllll}
\hline $\mathbf{7}$ & Berat & Berat & $80 \%$ & SESUAI \\
$\mathbf{8}$ & Berat & Berat & $75 \%$ & SESUAI \\
$\mathbf{9}$ & Berat & Ringan & $\mathbf{5 5 \%}$ & TIDAK SESUAI \\
$\mathbf{1 0}$ & Berat & Berat & $90 \%$ & SESUAI \\
\hline
\end{tabular}

Dari data uji yang dilakukan, maka diperoleh hasil sebagai berikut:

1. Sensitifitas

$$
\begin{aligned}
& \text { Sensitifitas } \frac{T P}{T P+F N} \times 100 \% \\
& \text { Sensitifitas } \frac{3}{3+1} \times 100 \%=75 \%
\end{aligned}
$$

2. Spesifisitas

$$
\text { Spesitifitas } \frac{T N}{F P+T N} \times 100
$$

$$
\text { Spesitifitas } \frac{5}{1+5} \times 100 \%=83 \%
$$

3. Akurasi

$$
\begin{aligned}
& \text { Akurasi } \frac{T P+T N}{\text { Total }} \times 100 \% \\
& \qquad \text { Akurasi } \frac{3+5}{10} \times 100 \%=80 \%
\end{aligned}
$$

Jadi, setelah melihat hasil pengujian yang telah dilaksanakan, dari 10 data uji yang dilakukan terdapat 8 data yang sesuai dengan hasil rekam medis, dan 2 data yang tidak sesuai yaitu data ke 6 dan data ke 9. Data ke 6, output sistem menghasilkan pneumonia berat tidak sesuai dengan rekam medis yang hasilnya pneumonia ringan, sedangkan data ke 9 , output sistem hasilnya pneumonia ringan tidak sesuai dengan rekam medis yang hasilnya pneumonia berat. Dua data uji tersebut memiliki variabel berbeda dengan variabel yang digunakan sehingga menghasilkan output yang tidak sesuai dengan diagnosis sistem. Dengan demikian diperoleh tingkat akurasi sebesar $80 \%$, nilai sensitifitas sebesar $75 \%$ dan nilai spesitifitas sebesar $83 \%$. Secara keseluruhan sistem dapat diterima dan dipergunakan untuk membantu proses diagnosis pneumonia pada anak.

\section{KESIMPULAN}

Penelitian sistem diagnosis pneumonia dengan fuzzy tsukamoto berhasil diimplementasikan dan di ujicoba. Berdasarkan hasil dan pengujian yang dilakukan mampu mendiagnosis pneumonia dengan klasifikasi yang benar berdasarkan gejala yang diderita pasien. Berdasarkan hasil uji coba dengan 10 data uji, fuzzy tsukamoto berhasil memberikan rekomendasi diagnosis 8 dari 10 data yang sesuai dengan hasil rekam medis. Fuzzy tsukamoto memberikan akurasi sebesar $80 \%$, sensitifitas sebesar $75 \%$ dan spesitifitas sebesar $83 \%$ dalam membantu diagnosis pneumonia pada anak.

\section{DAFTAR PUSTAKA}

[1] N. Fendi, U. P. Iswati, and Y. Ika, "Evaluasi penggunaan antibiotik pada penyakit pneumonia di RSUD PURBALINGGA," Pharmacy, vol. 08, no. 01, pp. 140-152, 2011.

[2] Kementrian Kesehatan Indonesia, Profil kesehatan Indonesia 2018. 2018.

[3] IDAI, "Buku Ajar RESPIROLOGI ANAK," Buku ajar respirologi anak, pp. 10-47, 2008.

[4] IDAI, "PEDOMAN PELAYANAN MEDIS IKATAN DOKTER ANAK INDONESIA," Pedoman Pelayanan Medis, p. 23, 2009.

[5] Kementrian Kesehatan Indonesia, "Hasil Riset Kesehatan Dasar Kementerian RI 2013," Proceedings, Annu. Meet. - Air Pollut. Control Assoc., vol. 6, 2013. 
[6] Kementrian Kesehatan Indonesia, PROFIL KESEHATAN INDONESIA TAHUN 2017. 2018.

[7] J. Razky, S. Rini, and Mandala Eka Praja Wijata, "Sistem Pakar Diagnosa Penyakit Pneumonia Pada Anak Menggunakan Metode Case Based Reasoning," SAINTEKS, vol. 6, no. ISBN : 978-602-52720-1-1, pp. 868-872, 2019.

[8] E. G. Wahyuni and A. S. Ramadhan, "Sistem diagnosis pneumonia menggunakan logika Fuzzy Tsukamoto," CITEE, no. ISSN: 2085-6350, pp. 24-26, 2018.

[9] E. P. Silmina and T. Hardiani, "PERANCANGAN SISTEM PAKAR PENYAKIT PNEUMONIA PADA BALITA MENGGUNAKAN ALGORITME K-NN ( K-NEAREST NEIGHBOR )," J. pseudocode, vol. V, no. September, 2018.

[10] F. Thamrin and E. Sediyono, "Studi Inferensi Fuzzy Tsukamoto Untuk Penentuan Faktor Pembebanan Trafo PLN," vol. 01, pp. 1-5, 2012.

[11] S. Kusumadewi, Artificial intelligence (Teknik dan Aplikasinya). Graha Ilmu, 2003.

[12] Kementrian Kesehatan Indonesia, MODUL TATALAKSANA STANDAR PNEUMONIA. Jakarta, 2012.

[13] S. Kusumadewi and H. Purnomo, Aplikasi Logika Fuzzy Edisi untuk Pendukung Keputusan Edisi 2. Graha Ilmu, 2010.

[14] Y. A. Maulana and B. Nurhadiyono, "Implementasi Fuzzy Tsukamoto dalam mendiagnosa penyakit diabetes melitus."

\section{BIOGRAFI PENULIS}

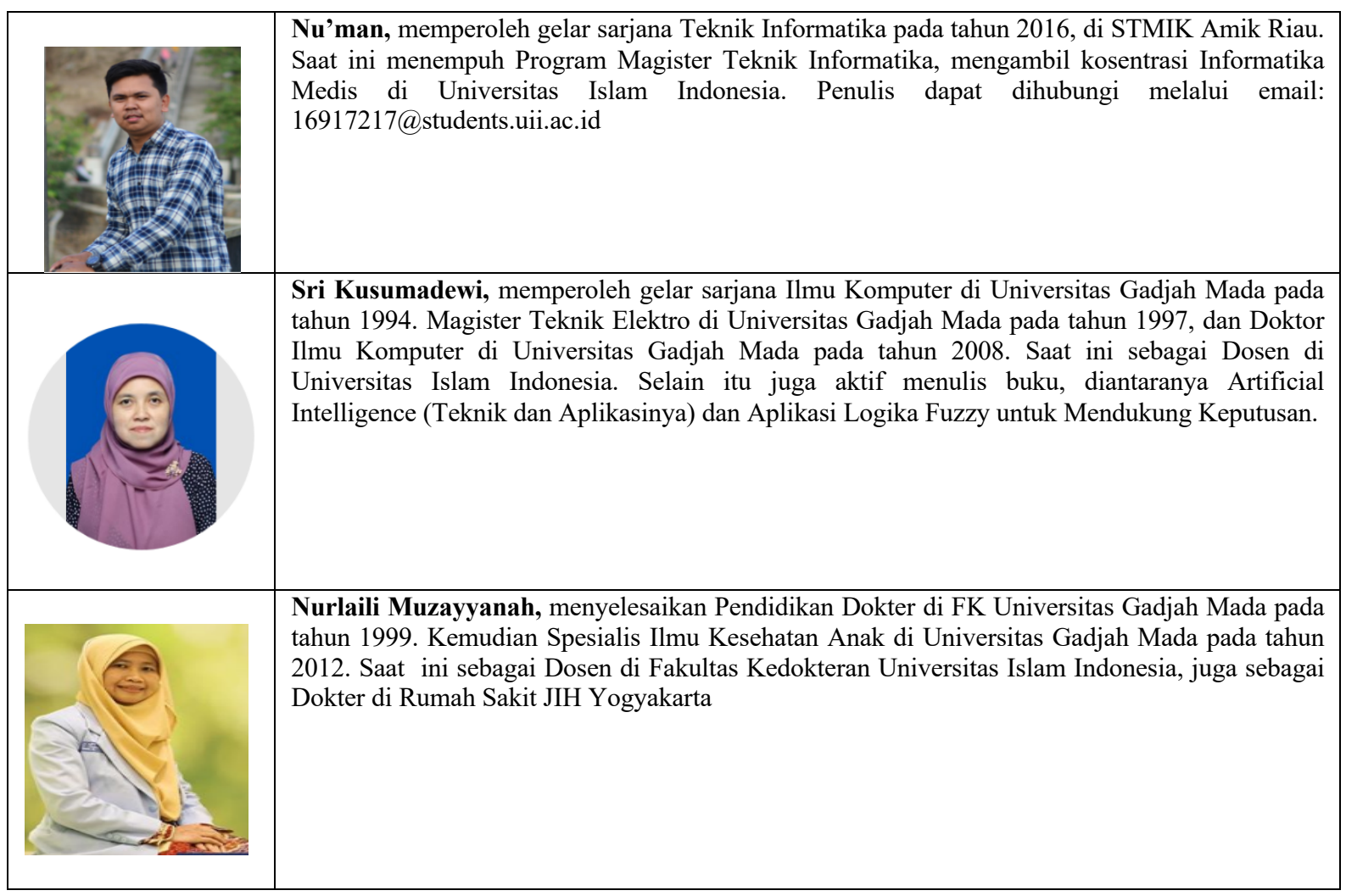

